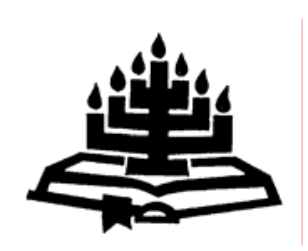

\title{
Die voorskrifte in 1 Timoteus 2:8-15 soos geïnterpreteer vanuit die breër tekstuele konteks van 1 Timoteus
}

\author{
Douw G. Breed \\ Skool vir Bybelwetenskappe en Bybeltale \\ Potchefstroomkampus \\ Noordwes-Universiteit \\ POTCHEFSTROOM \\ E-pos: dbreed@telkomsa.net
}

\begin{abstract}
The instructions in 1 Timothy 2:8-15 interpreted within a broader contextual perspective of 1 Timothy

Breed (2006a:247-263 and 2006b:453-463) has shown in two articles on 1 Timothy 2:8-15 that Paul does not give any indication in 1 Timothy 2 of whether his instructions to men and women are meant for public worship, ordinary life or marriage. Because Paul comments on the relations between men and women - an issue that is currently universally debated - in this article the broader textual context of 1 Timothy 2:8-15 is investigated to see whether it illuminates Paul's instructions to men and women. The study focuses on the false teachings that Paul opposed, and on the aim of this letter. The structure of thought of 1 Timothy is analysed closely to determine whether there are references to marriage in 1 Timothy and to explore the possibility that in 1 Timothy 2:8-15 Paul actually states the true teaching concerning marriage in opposition to false teachings. This study concludes that there are strong indications that in 1 Timothy 2:8-12 Paul is considering the conduct between men and women in marriage, rather than conduct during public worship or in ordinary life.
\end{abstract}

\section{Opsomming}

Die voorskrifte in 1 Timoteus 2:8-15 soos geïnterpreteer vanuit die breër tekstuele konteks van 1 Timoteus

Breed (2006a:247-263 en 2006b:453-463) toon aan dat Paulus nie in 1 Timoteus 2 werklik 'n aanduiding gee of hy in dié gedeelte voorskrifte gee vir die erediens, die gewone lewe of 
die huwelik nie. Juis omdat Paulus in hierdie gedeelte handel oor die verhouding tussen mans en vroue - 'n saak wat tans wêreldwyd aandag geniet - word daar in hierdie artikel ondersoek ingestel of die breër tekstuele konteks van 1 Timoteus 2:8-15 nie meer lig op Paulus se voorskrifte aan mans en vroue werp nie. In die ondersoek word aandag gegee aan die vals leer wat Paulus in die brief bestry en die doel van die brief. 'n Nadere ontleding van die gedagtestruktuur van 1 Timoteus 2 word gedoen, asook van die verwysings na die huwelik in 1 Timoteus en die moontlikheid dat Paulus in 1 Timoteus 2:8-15 die suiwer leer aangaande die huwelik teenoor die vals leer aangaande die huwelik stel. Die bevinding in die artikel is dat daar sterk aanduidings is dat Paulus nie oor gedrag in die erediens of die gewone lewe handel nie, maar oor die gedrag van mans en vroue in die huwelik.

\section{Inleiding}

Breed (2006a:247-263 en 2006b:453-463) toon aan dat daar nie uit 1 Timoteus 2:8-15 afgelei kan word of Paulus ${ }^{1}$ in dié gedeelte oor die gedrag van mans en vroue in die erediens, die huwelik of die gewone lewe handel nie. Omdat Paulus in hierdie gedeelte oor 'n saak handel wat tans wêreldwyd baie aandag geniet, te wete die verhouding tussen mans en vroue, is dit van groot belang dat groter duidelikheid oor hierdie gedeelte verkry moet word. Daar word daarom in hierdie artikel gepoog om 1 Timoteus 2:8-15 in die breër tekstuele konteks van 1 Timoteus te verstaan.

In die ondersoek van die breër tekstuele konteks word opeenvolgend aan die volgende sake aandag gegee: 'n moontlike gedagtestruktuur van 1 Timoteus; die vals leer wat Paulus in die brief bestry; die doel van die Timoteusbrief; 'n nadere ontleding van die gedagtestruktuur van 1 Timoteus 2; die huwelik volgens 1 Timoteus en laastens die moontlikheid dat Paulus in 1 Timoteus 2:8-15 bekend maak wat die suiwer leer aangaande die huwelik is en dit stel teenoor die vals leer wat aangaande die huwelik in Efese verkondig is. Ná hierdie sake ondersoek is, word 'n samevatting van al die gevolgtrekkings waartoe in die artikel gekom is, gegee en

1 Mounce (2000:xlviii-cxxix) wys daarop dat die besware wat skrywers teen Paulus se outeurskap uitlig, hoofsaaklik van historiese, teologiese en literêre aard is. Hy gee volledig aan hierdie besware aandag en toon oortuigend aan dat met groot vrymoedigheid aanvaar kan word dat 1 Timoteus deur Paulus geskryf is. Ook studies van Guthrie (1979:15-31) en Ridderbos (1967:14-32) dui aan dat die besware teen Paulus se outeurskap nie werklik gegrond is nie. 
word tot 'n finale gevolgtrekking gekom. Voordat die bibliografie gegee word, word die terreine vir verdere ondersoek aangedui.

\section{2. 'n Moontlike gedagtestruktuur van 1 Timoteus}

Die volgende uiteensetting sou as gedagtestruktuur van 1 Timoteus kon dien (Breed, 2006a:247-263):
1:1-2 Die aanhef.
1:3-20 Die opdrag aan Timoteus.
2:1-6:2a Betaamlike optrede van mense wat tot God se huisgesin behoort teenoor die leer en gedrag wat die vals leraars voorgestaan het.

6:2b-19 Finale opdragte.

6:20-21 Briefslot.

Die gedeelte waarbinne 2:8-15 voorkom, te wete 2:1-6:2a sou soos volg in kleiner gedagte-eenhede uiteengesit kon word:

2:1-15 Gedrag van gelowiges.

3:1-13 Gedrag van ouderlinge en diakens.

3:14-16 Die doel van die brief: gedrag van God se huisgesin (vgl. 4.1).

4:1-14 Die leer en gedrag van die vals leraars.

5:1-6:2a Gedrag van verskillende groepe binne die kerk.

\section{Die vals leer wat Paulus bestry}

\subsection{Aanduidings van die vals leer wat Paulus in 1 Timoteus bestry}

Verskeie pogings is al aangewend om vas te stel wat die vals leer is wat in 1 Timoteus bestry word. Volgens Mounce (2000:Ixx) kan aanvaar word dat daar in 1 Timoteus sprake is van 'n soort protognostisisme. Hy lei dit af uit die feit dat die leraars asketisme en bandeloosheid voorgestaan het en dat hulle 'n lae dunk van die fisieke wêreld gehad het. 
Towner (1989:30) verwys na 2 Timoteus 2:18 en sê dat die vals leer op 'n verkeerde interpretasie van Paulus se verkondiging aangaande die opstanding van gelowiges berus het. Omdat Paulus geleer het dat gelowiges saam met Christus gesterf en opgestaan het (vgl. Rom. 6:8), het hulle 'n toekomstige vervulling van die beloftes van die opstanding van gelowiges ontken. Towner vergelyk die leer in Efese met die vals leer wat in Korinthe verkondig is en noem dit 'n "over-realized eschatology". Volgens Towner verklaar die leraars se beskouing van die opstanding ook hulle opdrag dat mense hulle moet onthou van sekere voedsel en nie moet trou nie. Hulle het aanvaar dat hierdie dinge tot die ou bedeling hoort en nie tot die bedeling wat reeds aangebreek het nie.

Young (1994:48-59) toon aan dat die skrywer van die Pastorale Briewe God se universele heerskappy beklemtoon en God as Verlosser voorgehou het. Ook Mounce (2000:Ixx, 75-92) wys daarop dat die skrywer van 1 Timoteus die redding van mense sterk op die voorgrond plaas. Paulus beveel byvoorbeeld in 2:1-7 dat vir "alle mense" gebid moet word; hy sê dat God wil hê dat alle mense gered word en maak dit duidelik dat Christus Homself as losprys vir almal gegee het. Die klem op alle mense dui volgens Mounce daarop dat die leraars waarskynlik gepoog het om gelowiges te oortuig dat die evangelie nie aan alle mense verkondig mag word nie.

Hoewel daar met redelike sekerheid aanvaar kan word dat bostaande afleidings van Mounce, Towner en Young gegrond is, is dit uit 1 Timoteus duidelik dat Paulus slegs in 4:3 'n uitdruklike aanduiding gee wat die inhoud van die vals leer was wat hy bestry het. Die leraars het volgens hierdie vers spesifieke sake aangaande die eet van kos en die huwelik verkondig. Hulle het mense verbied om te trou en hulle beveel om hulle van sekere kos te onthou.

Dit blyk verder uit die brief dat daar met sekerheid aanvaar kan word dat die leraars hulle op die Ou Testament beroep het. Volgens 1:7 het dié mense hulleself as leraars van die "wet" beskou. Dit is uit 1:8-10 duidelik dat Paulus met wet na die wet van Moses verwys, wanneer hy in dié gedeelte die regte gebruik van die wet van Moses kontrasteer met die wyse waarop die leraars dit gebruik. Sumney (1999:258) wys ook daarop dat die fabels en geslagsregisters wat in 1:4 vermeld word, waarskynlik te doen het met die wyse waarop die leraars gedeeltes van die Ou Testament uitgelê het. Dit val verder op dat Paulus in 1 Timoteus 4:3-4 die Ou Testament gebruik om die leraars se opdrag aan mense, om hulle van sekere voedsel te onthou, te bestry (vgl. Borse, 1985:51). 
Uit die voorgaande kan die volgende gevolgtrekkings aangaande die vals leraars en hulle leer gemaak word:

- Dit is 'n sterk moontlikheid dat dié leraars 'n vroeë vorm van gnostisisme verkondig het; dat hulle hulle standpunte op 'n "overrealized eschatology" gegrond het en dat hulle mense probeer oortuig het dat die evangelie nie vir alle mense bedoel was nie.

- Die vals leraars was teen die huwelik gekant en het mense verbied om sekere kos te eet.

- Die vals leraars het in die verkondiging van hulle leer die Ou Testament gebruik. Teenoor die wyse waarop die leraars die Ou Testament uitgelê het, stel Paulus 'n ander uitleg. Wanneer Paulus dus in 1 Timoteus na die Ou Testament verwys, behoort in gedagte gehou te word dat hy moontlik 'n verkeerde uitleg deur die vals leraars bestry.

\subsection{Die voorskrifte in 1 Timoteus 2:8-15 in die lig van die leer wat deur die vals leraars verkondig is}

Die voorafgaande werp die volgende lig op 1 Timoteus 2:8-15:

- Die vals leraars het spesifiek 'n vals leer aangaande die huwelik verkondig. Dit is waarskynlik dat Paulus in die brief wat hy tot Timoteus rig, en waarin hy die leer van die leraars bestry, behoorlike aandag sal gee aan 'n suiwer leer aangaande die huwelik.

- Die feit dat Paulus in 1 Timoteus 2:13-15 sy voorskrifte in 2:11-12 op die Ou Testament begrond, is belangrik. Dit gee in die lig van die laaste gevolgtrekking in 3.1 'n moontlike aanduiding dat Paulus in 2:11-15 besig is om die vals leer van die leraars te bestry.

\section{Die doel van die brief}

\subsection{Aanduidings in 1 Timoteus van die doel van die brief}

Daar is in die verlede al op verskeie sake gewys wat in die Pastorale Briewe klem ontvang en wat 'n aanduiding kan gee van die doel waarom die brief geskryf is. Kidd (1990:92) wys op die klem wat in hierdie brief op rykdom geplaas word en sê die gedrag wat die skrywer voorskryf "involves managing the church's financial resources and learning how to minister to the congregation's 
wealthier members" (vgl. in hierdie verband Barnett, 1989:225-228 en Harris, 1990:335-339). Verner (1983:175-186) sê dat die skrywer van die Pastorale Briewe 'n bedreiging teen die established order wou afweer en dat sy doel met die brief is "to bolster a hierarchical social structure in the church". Dit is inderdaad so dat die gedrag wat Paulus in die brief voorskryf, verband hou met finansiële sake (vgl. byvoorbeeld 3:3; 6:5 en 6:17-19) en dat die hantering van gesag (vgl. byvoorbeeld 2:9-15 en 6:1-2) 'n besondere plek in die brief inneem. Daar is egter ander sake wat ook in die brief beklemtoon word en daar kan aanvaar word dat Paulus se voorskrifte aangaande die hantering van gesag en rykdom nie die volle doel van die brief omvat nie.

Daar is in 1 Timoteus drie gedeeltes waarin Paulus die doel van sy skrywe vermeld, te wete 1:3-7 (Wiebe, 1994:56), 1:18-20 en 3:14-16 (Holmes, 2000:111). Wanneer hierdie drie gedeeltes nader bestudeer word, val dit op dat die bevordering van 'n lewenswandel wat van die suiwer leer getuig, sentraal staan in die doel van die brief. Paulus wys in 1:3 daarop dat die vals leraars met hulle leer net twisvrae bevorder en nie rentmeesterskap ${ }^{2}$ nie. Teenoor hierdie lewenswandel wat deur die vals leer bevorder word, stel Paulus in 1:5 'n lewe wat gekenmerk word deur liefde uit 'n rein hart en 'n goeie gewete en 'n ongeveinsde geloof. Hierdie leefwyse moet

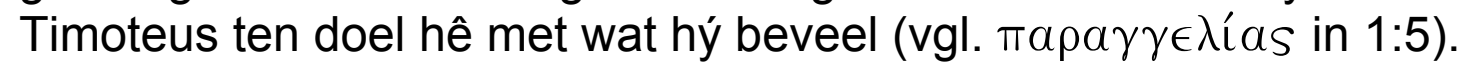

In 1:19 beklemtoon Paulus ook die lewenswandel van gelowiges. Nadat hy in 1:18 gestel het dat hy die suiwer leer aan Timoteus toevertrou het, en hom opgeroep het om die goeie stryd te stry, sê hy dat Timoteus op sy lewenswandel moet let. Hy sê Timoteus moet aan die geloof en 'n skoon gewete vashou. Paulus wys in 1:19-20 wat gebeur wanneer mense nie hulle lewe volgens die suiwer leer inrig nie. Die vals leraars het die geloof en 'n goeie gewete van hulle af weggestoot en die gevolg is dat hulle die Christelike geloof skade aangedoen het (vgl. Mounce, 2000:66-70).

Volgens 3:15 wil Paulus dat Timoteus sal weet hoe mense hulle in

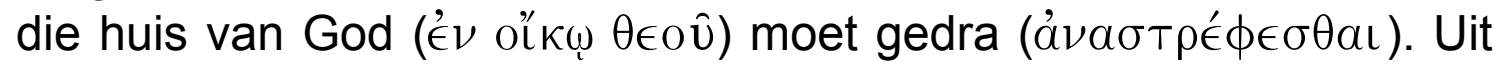

2 Dit is moontlik dat oíкориíav in 1:4 na God se plan vir die redding van die mensdom verwys (vgl. Louw \& Nida, 1988:358-359). Omdat die woord

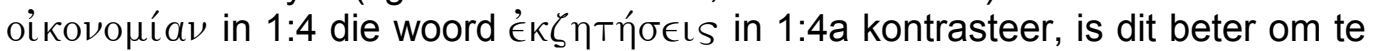

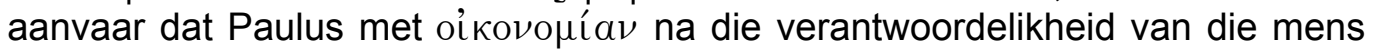
ten opsigte van God se plan verwys. Die woord kan daarom vertaal word met rentmeesterskap. 


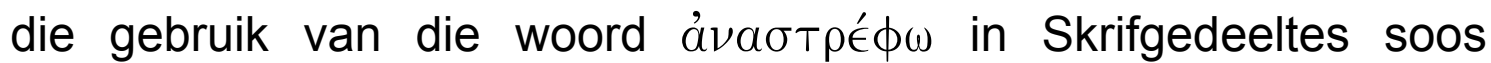
Efesiërs 2:3, Hebreërs 3:5-6, 10:21 en 1 Petrus 4:17 is dit duidelik dat die woord gebruik word om die "general conduct, a person's way of life" aan te toon (Mounce, 2000:220). Die gedrag wat vereis word

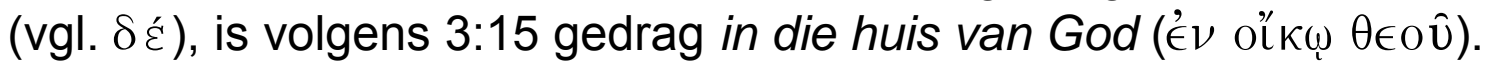
Towner (1989:133-134) toon oortuigend aan dat die skrywer met oíkos die kerk as huishouding in gedagte het. Dit blyk dat Paulus die brief aan Timoteus skryf sodat Timoteus sal weet hoe mense wat deel van God se huisgesin is, hulle lewe moet inrig.

In 3:14-16 stel Paulus die suiwer leer op die voorgrond, deur na die gemeente as die pilaar ( $\sigma \tau \hat{v} \lambda o s)$ en grondslag3 $3(\dot{\epsilon} \delta \rho \alpha \hat{i} \omega \mu \alpha)$ van die waarheid ( $\left(\dot{\lambda} \lambda \eta \epsilon^{\prime} \dot{\imath} \alpha\right)$ te verwys. Mounce (2000:86) en Kelly (1972:62) toon aan dat die woord $\alpha \lambda \eta \theta \epsilon i ́ \alpha$ in die Pastorale Briewe na die hele openbaring van God in Christus verwys. Van hierdie waarheid is die gemeente die pilaar en grondslag. Spicq (1969:464-466) maak dit duidelik dat die skrywer deur die gemeente as grondslag en pilaar van die waarheid te beskryf, op die taak van die gemeente wys om die waarheid te beskerm en te verkondig. Paulus leer wel dat die kerk op die waarheid gebou is (vgl. Ef. 2:19-20), maar in 1 Timoteus 3:15 beklemtoon hy dat die kerk 'n verantwoordelikheid het teenoor die waarheid waarop hy gebou is. Teenoor die leefwyse wat deur die vals leer bevorder word, moet die gelowiges hulle sodanig gedra dat hulle nie die openbaring van God (die waarheid) in onguns bring nie. Die kerk moet as pilaar en grondslag van die waarheid, deur hulle leefwyse, hierdie waarheid verdedig en uitdra.

\subsection{Gevolgtrekking}

Uit die voorgaande is dit duidelik dat Paulus deur die brief wat hy aan Timoteus rig, dit ten doel stel dat die gelowiges in Efese se lewenswandel met die suiwer leer sal ooreenstem. Paulus wil voorkom dat Timoteus of die ander gelowiges in Efese deur slegte rentmeesterskap die suiwer leer in onguns bring by die ongelowiges. Paulus wil dat die gelowiges, as mense wat deel is van God se huishouding, die suiwer leer sal beskerm en dit deur hulle leefwyse verkondig.

3 Vgl. Louw en Nida (1988:378) vir die betekenis waarvoor die woord $\dot{\varepsilon} d r$ a íwma gebruik word. 


\subsection{Timoteus 2:8-15 in die lig van die doel van die brief}

Wanneer in ag geneem word dat die gelowiges se gedrag en die boodskap wat dit aan die ongelowiges oordra, sentraal staan in die doel van die brief, lyk dit meer waarskynlik dat Paulus in 1 Timoteus 2:8-15 oor die gedrag van mans en vroue in die algemeen of in die huwelik sal handel, as oor hulle gedrag in die erediens. Die gelowiges se gedrag in die erediens was immers net by uitsondering (vgl. 1 Kor. 14:23-24) vir die ongelowiges sigbaar. 'n Finale afleiding kan egter nie in die lig van die doel van die brief gemaak word nie, aangesien Paulus dit om een of ander rede nodig kon ag om in die brief aan Timoteus in 2:8-15 sake aan te raak wat nie direk inpas by die doel van die brief nie. Dit sou daarom nodig wees om 'n nadere ontleding te maak van die gedagtestruktuur van 1 Timoteus 2 , om ondersoek in te stel of Paulus wel in dié gedeelte die doel van die skrywe aan die orde stel.

\section{5. 'n Nadere ontleding van 'n gedagtestruktuur van 1 Timoteus 2}

\subsection{Die ontleding van 'n gedagtestruktuur}

Schreiner (1995:117) sê dat die hele gedagtegang van 1 Timoteus daarop wys dat die skrywer in 1 Timoteus 2:8-15 oor optrede in die openbare erediens handel. Hy sê:

The flow of thought of 1 Timothy as a whole commends a public setting. False teachers are threatening the church, and Timothy is charged to stem the tide of their influence. First Timothy 2:815 is succeeded by an exhortation to appoint overseers and deacons in the church (1 Tim. 3:1-13), and both are offices that relates to public ministry in the church.

Dit is inderdaad so dat die dienste van opsieners en diakens verband hou met public ministry. 'n Afleiding dat die verwysing na opsieners en diakens ' $n$ public setting vereis, is egter nie geldig nie. Wanneer Paulus oor die diakens en opsieners handel, gaan dit immers nie slegs oor hulle dienswerk in die erediens nie. Paulus beklemtoon eerder in die algemeen die vereistes waaraan iemand moet voldoen om 'n opsiener of diaken te wees.

Dit blyk dat dit nodig is om 'n behoorlike ondersoek te doen na die gedagtestruktuur van 1 Timoteus 2 alvorens daar enige afleidings gemaak word oor die betekenis daarvan vir die verstaan van 1 Timoteus 2:8-15. 
In punt 2 is aangedui dat die vals leraars hulle in die verkondiging van hulle leer op die Ou Testament beroep het, en dat hulle waarskynlik die uitdra van die evangelie aan alle mense teëgestaan het. Daar is ook reeds gestel (vgl. 3.4) dat Paulus teenoor hierdie vals leer in 2:1-7 die suiwer leer verkondig. In 2:1-7 maak Paulus duidelik dat die gelowiges in Efese in ooreenstemming met God se wil optree indien hulle aan elke mens die waarheid verkondig. 4 Paulus noem God 'n Verlosser (v. 3); hy sê God wil dat alle mense gered word en tot die kennis van die waarheid kom (v. 4); ook in vers 5 beklemtoon hy die redding van ongelowiges wanneer hy sê dat daar één God is. Ridderbos (1979:338) toon aan dat die woorde $\epsilon \hat{i} s$ yà $\theta \epsilon o ́ s$ in vers 5 ooreenkomste toon met die Joodse Shema

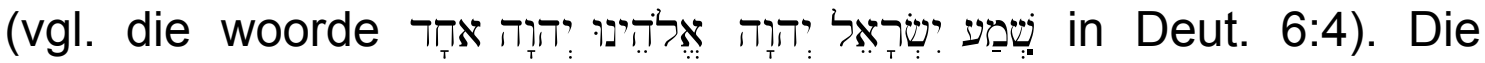
Joodse Shema wys enersyds op die eenheid van God, maar ook op sy enigheid (Vriezen, 1977:350-356). Die enigheid van God bevestig vir Paulus die feit dat die evangelie nie net vir sekere mense bedoel is nie, maar vir almal. "All men have to do with one God in judgment and in grace" (Ridderbos, 1979:339). Hierby voeg Paulus ook nog die feit dat daar maar één Middelaar tussen God en die mense is: die mens Jesus Christus. Hy beklemtoon daarmee verder die noodsaak dat die waarheid aan alle mense verkondig moet word. Daar is immers geen ander Middelaar as Jesus Christus nie. Paulus vermeld ook spesifiek in vers 6 dat hierdie Middelaar Homself as losprys vir almal gegee het. Ook in vers 7 gee die skrywer 'n motivering waarom die evangelie aan ongelowiges verkondig moet word. Hy beklemtoon spesifiek dat hy 'n leraar van die heidene is en dat hy daartoe aangestel is. As die gelowiges dus die evangelie aan heidene verkondig, tree hulle in ooreenstemming op met die opdrag wat Paulus van God ontvang het.

Daar is in punt 4.2 bevind dat die lewenswandel van gelowiges 'n belangrike plek in die doel van die brief inneem. Paulus wil dat gelowiges deur 'n lewenswandel wat ooreenstem met die suiwer geloof, die ongelowiges tot geloof moet roep. Dit blyk dat Paulus in 1 Timoteus 2 hierdie lewenswandel, uitdruklik aan die orde stel. In 2:1-3 gee hy opdrag tot voorbidding vir alle mense, vir konings en almal wat hooggeplaas is. Die doel van hierdie voorbidding is dat die gelowiges 'n rustige en stil lewe sal lei. Hierdie "rustige en stil lewe"

4 Hierteenoor beweer Davies (1996:34-35) dat daar nêrens in die brief aanduidings is dat die skrywer van die brief die uitdra van die evangelie aan ongelowiges beklemtoon nie. 
wys nie op die gelowiges se innerlike gesteldheid nie (Mounce, 2000:82). Dit gaan vir Paulus, soos in 1 Tessalonisense 4:11, oor 'n lewe waarin die gelowiges nie in konflik met ander mense staan nie. Paulus beskryf hierdie rustige en stil lewe verder met die woorde

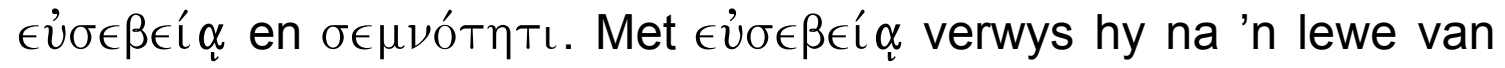
toewyding aan God, waarin die mens aan God se wil gehoorsaam is

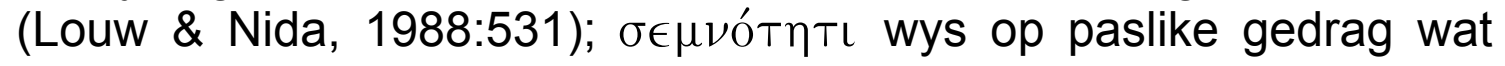
waardig is en wat respek by ander mense afdwing (Louw \& Nida, 1988:747-748). Wanneer die gelowiges dus die geleentheid ontvang om 'n lewe sonder konflik (rustig en stil) te lei, moet dit nie vir eie gemak gebruik word nie. Gelowiges moet die geleentheid gebruik om so te leef dat hulle lewe toewyding aan God vertoon en respek by ander afdwing.

Wanneer Paulus in 2:3 motiveer "want dit is goed en aangenaam voor God, ons Verlosser wat wil hê dat alle mense gered word en tot die kennis van die waarheid kom", word dit duidelik waaroor hierdie lewe van godsvrug en waardigheid gaan. Deur 'n lewe van godsvrug en waardigheid te lei, tree gelowiges in ooreenstemming met God se wil op, dat alle mense gered word. Deur hulle lewenswandel verkondig hulle die waarheid en kan mense "tot die kennis van die waarheid kom" (De Kruijf, 1966:36).

Dit is duidelik dat Paulus 'n lewe van godsvrug en waardigheid in 2:8 aan die orde stel. Hy wil volgens 2:8 dat mans "heilige hande" moet ophef en dat hulle vry moet wees van "toorn of twis". Die heilige hande verwys na hande wat gereinig is van sondige dade (vgl. Eks. 30:17-21; Jak. 4:8 en 1 Pet. 3:7). Met die woorde toorn en twis wys Paulus waarskynlik op die sondige dade waarvan mans se hande gereinig moet wees. Die mans se hande moet heilig wees deurdat hulle nie toorn koester en in twis lewe nie.

Dit blyk dat Paulus ook in verse 9-12 oor 'n godvrugtige en waardige lewe handel. Hy beklemtoon in vers 10 dat vroue hulle só moet versier dat dit getuig van hulle geloof en verhouding met God.5 Paulus beklemtoon ook in vers 10 vroue se verantwoordelikheid tot goeie werke ("€́p $\gamma(\omega \nu \alpha \hat{\gamma} \gamma \alpha \theta \hat{\omega} \nu)$. Daar kan afgelei word dat Paulus ook, wanneer hy van vroue eis dat hulle hul sal laat leer en nie aan mans onderrig sal gee of oor die man heers nie (2:11-15), hierdie godvrugtige en waardige lewe aan die orde stel.

5 Vergelyk Louw en Nida (1988:539) vir die betekenis waarvoor die woord $\theta \in O \sigma \epsilon ́ \beta \in \iota \alpha \nu$ in 2:10 gebruik word. 


\subsection{Gevolgtrekkings}

Uit die voorafgaande kan die volgende afleidings gemaak word:

Die lewenswandel van gelowiges staan in 1 Timoteus 2 op die voorgrond. Deur hulle lewenswandel moet gelowiges, in ooreenstemming met God se wil, ongelowiges tot die kennis van die waarheid lei (2:1-7). In 2:8-15 laat Paulus blyk hoe die lewenswandel van gelowige mans en vroue lyk wat aan heidene die waarheid verkondig.

Die volgende uiteensetting gee 'n waarskynlike gedagtestruktuur van 1 Timoteus 2 weer:

2:1-2 Opdrag tot voorbidding sodat gelowiges 'n rustige en stil lewe van godsvrug en waardigheid sal lei.

2:3-7 Motivering waarom gelowiges 'n lewe van godsvrug en waardigheid moet lei: die redding van mense.

- God is 'n Verlosser (v. 3).

- God wil dat alle mense gered word en tot kennis van die waarheid kom (v. 4).

- Daar is maar één God en Middelaar deur wie mense gered kan word (v. 5).

- Christus het Homself gegee as losprys vir almal (v. 6).

- Wie gerig is op die redding van sondaars, tree in ooreenstemming met Paulus se roeping op (v. 7).

2:8 'n Godvrugtige en waardige optrede van mans wat in ooreenstemming met God se wil mense tot redding en kennis van die waarheid sal lei.

2:9-15 Godvrugtige en waardige optrede van vroue wat in ooreenstemming met God se wil mense tot redding en kennis van die waarheid sal lei.

\subsection{Betekenis van die gedagtestruktuur vir die verstaan van die voorskrifte in 1 Timoteus 2:8-15}

Omdat Paulus in hoofstuk 2 oor die waardige optrede van mans en vroue handel - optrede wat tot redding van mense en tot kennis van die waarheid moet lei - is dit meer waarskynlik dat hy in 1 Timoteus 2:8-15 oor die gedrag van mans en vroue in die algemeen of in die 
huwelik handel, as oor hulle optrede in die erediens. Soos in 4.3 gestel, was mans en vroue se optrede in die erediens immers net by uitsondering vir die ongelowiges sigbaar, dit is wanneer die ongelowiges die erediens sou besoek.

\section{Die huwelik in 1 Timoteus}

Paulus skenk in 1 Timoteus uitdruklik aandag aan die huwelik. Hy is besorg oor die huwelike van voorgangers, te wete van die opsieners (3:2), diakens (3:12) en weduwees wat 'n besondere diens sou doen (5:9). Hy beklemtoon dat jong weduwees moet trou, kinders hê en hulle huise bestuur $(5: 14)$. Sy erns met die huwelik, veral sy erns met die huwelike van voorgangers, laat blyk dat die verkondiging

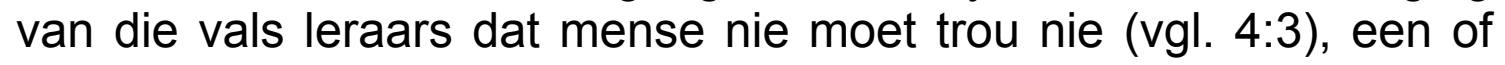
ander probleem met betrekking tot die huwelik in die gemeente veroorsaak het. Vir die doeleindes van hierdie artikel is dit belangrik om hierdie probleem nader te probeer ontleed.

\subsection{Die huwelike van voorgangers}

Paulus sê dat sowel 'n opsiener as 'n diaken 'n man van een vrou

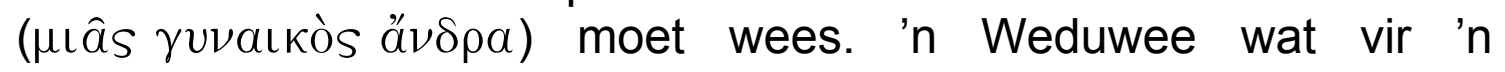
besondere diens afgesonder word, moet die vrou van een man

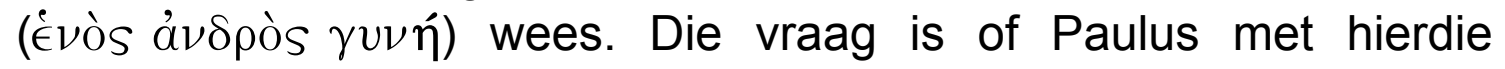
woorde oor poligamie/poliandrie, hertroue ná die huweliksmaat se dood, hertroue ná egskeiding of ontrouheid in die huwelik handel.

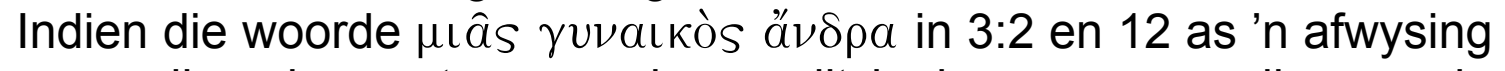
van poligamie verstaan word, sou dit logies wees om die woorde

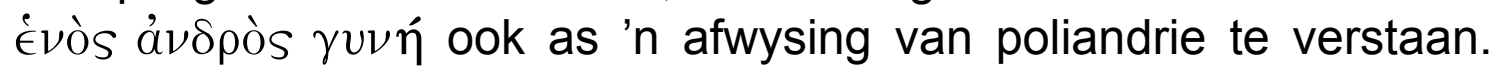
Paulus sou dus vereis dat 'n vrou wat volgens 5:9 gekies word, nie meer as een man mag hê nie. Towner (1989:231) wys daarop dat daar nie werklik enige aanduiding is van poliandriese huwelike in die tyd van die Nuwe Testament nie. Dit blyk dus dat Paulus nie in hierdie vers na poligamie of poliandrie verwys nie.

Die feit dat Paulus in 5:14 aanbeveel dat jong weduwees weer moet trou, gee 'n aanduiding dat hy nie hertroue as in stryd met God se wil beoordeel nie. Daar kan daarom aanvaar word dat hy nie sou vereis dat iemand net een keer getroud moes wees om 'n voorganger te wees nie.

Hertroue ná egskeiding was in die tyd van die Nuwe Testament nie in alle gevalle verbied nie (vgl. Matt. 5:32 en 19:9 en moontlik 1 Kor. 7:15). Daaruit sou afgelei kan word dat Paulus nie met die woorde

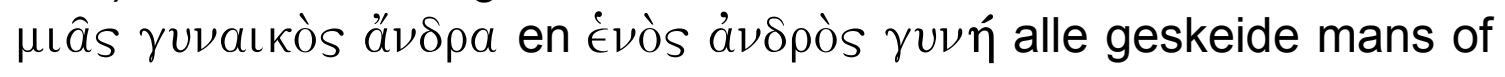


vroue wat hertrou het, sou verbied om sekere dienste in die kerk te doen nie.

Saam met verskeie eksegete (Holmes, 2000:148-149; Okorie, 1988:159-166; Ridderbos, 1967:90) kan aanvaar word dat die

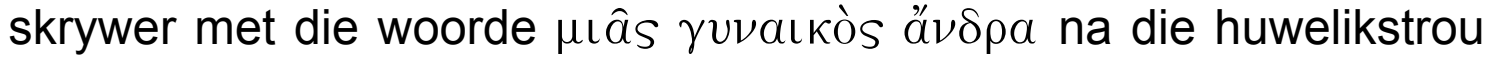
van die betrokke voorgangers verwys. Indien Paulus in 3:2 en 3:12

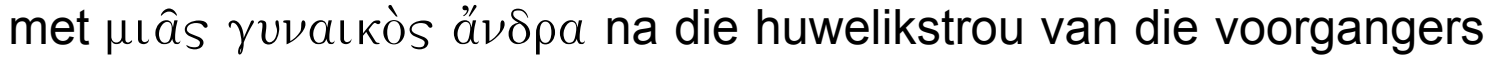
verwys, stel hy daarmee 'n morele vereiste vir die voorganger. Dit kom ooreen met die ander vereistes vir opsieners en diakens in 1 Timoteus 3, wat ook morele vereistes is. In die lig van die lae aansien wat die huwelik by die vals leraars gehad het, sou die vereiste van huwelikstrou 'n duidelike korreksie op hierdie beskouing wees. Paulus het dus met die woorde $\mu \iota \hat{s}$ juvaıkòs ă $\nu \delta \rho a$ en $\dot{\epsilon} \nu$ òs $\alpha \nu \delta \rho o ̀ s ~ \gamma v \nu \eta ́$ die huwelikstrou van voorgangers in gedagte. Hy wil dat voorgangers in die kerk mense moet wees wat deur hulle huwelikstrou aan almal toon dat hulle - anders as die vals leraars die huwelik hoog ag.

\subsection{Die huwelike van jong weduwees}

In die lig van die doel van 1 Timoteus, soos dit in punt 3 uiteengesit is, val dit op dat wanneer Paulus oor die huwelike van jong weduwees handel, hy die huwelik as getuienis aan ongelowiges voorhou. Nadat Paulus in 5:14 duidelik gemaak het dat hy wil hê dat jong weduwees moet trou, kinders in die wêreld bring en hulle huise bestuur, motiveer hy hoekom dit van hulle verwag word. Hy sê hulle moenie die Teëstaander 6 aanleiding gee om kwaad te praat nie. Hy skets in 5:11-13 die gedrag van die weduwees wat wel die Teëstaander aanleiding sal gee om kwaad te praat. As weduwees

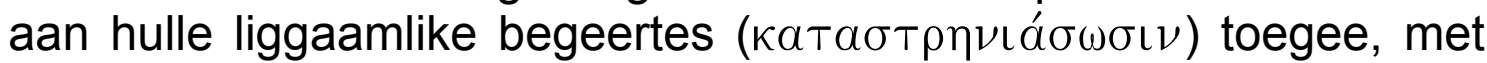
ongelowiges trou en hulle geloof in Christus verloën, 7 sou hulle aan die Teëstaander aanleiding gee om kwaad te praat. Ongelowiges sou onder die leiding van Satan rede hê om sleg te praat van die kerk. Wanneer 'n gelowige weduwee egter (met 'n gelowige man) trou, kinders in die wêreld bring en haar huis bestuur, sou daar nie

6 Mounce (2000:296) toon aan dat Paulus met $T \hat{\varphi} \alpha \dot{\alpha} \nu \tau \iota \kappa \in \iota \mu \dot{\epsilon}^{\prime} \nu \omega$ na Satan verwys (vgl. ook 1 Tim. 3 waar Paulus duidelik maak dat Satan aktief in die kerk werksaam is).

7 Vergelyk Mounce (2000:289-292) vir 'n volledige motivering van hierdie interpretasie van 1 Timoteus 5:11-15. 
geleentheid vir ongelowiges wees om onder leiding van die Satan van die kerk kwaad te praat nie. Die huwelik van hierdie weduwees sou dan eerder as 'n getuienis aan ongelowiges kon dien.

\subsection{Uitdruklike voorskrifte vir die huwelik in 1 Timoteus}

Hoewel Paulus in die gedeeltes waarin hy na die huwelik verwys, wel aandag gee aan die huwelik van die voorgangers en jong weduwees, val dit op dat hy in dié gedeeltes nie uitdruklik aan Timoteus voorskrifte vir die huwelik gee nie. Hy stel dus nie in dié gedeeltes die ware leer aangaande die huwelik teenoor die vals leer wat verkondig is nie.

\subsection{Gevolgtrekking}

Die verkondiging van die vals leraars aangaande die huwelik het in die kerk van Efese probleme veroorsaak. Hierdie probleme het verband gehou met die aansien wat die huwelik by die gelowiges geniet het. Die vals leraars het mense verbied om te trou wat daartoe kon lei dat gelowiges die huwelik nie na waarde ag nie. Wanneer Paulus in 1 Timoteus huwelikstrou as vereiste vir voorgangers stel, moet dit gesien word teen die agtergrond van die vals leer wat aangaande die huwelik in Efese verkondig is.

Paulus maak ook in sy opdragte aan die jong weduwees dit duidelik dat die huwelik ' $n$ belangrike getuienis na buite is. Wanneer jong weduwees trou, kinders in die wêreld bring en hulle huise bestuur, gee hulle daarmee nie geleentheid aan die Satan om die kerk in 'n slegte lig te stel nie.

Dit val op dat Paulus nie in die gedeeltes waarin hy na die huwelik verwys, positiewe voorskrifte gee waarin hy, teenoor die vals leer wat oor die huwelik in Efese verkondig is, die suiwer leer aangaande die huwelik stel nie.

\subsection{Betekenis van Paulus se verwysings na die huwelik vir die verstaan van die voorskrifte in 1 Timoteus 2:8-15}

Soos in 6.4 aangedui, gee Paulus nie in die gedeeltes waarin hy in 1 Timoteus na die huwelik verwys, positiewe voorskrifte waarin die suiwer leer aangaande die huwelik teenoor die vals leer wat die leraars in Efese verkondig het, gestel word nie. Hoewel Paulus in 1 Timoteus 2:8-15 nie uitdruklik na die huwelik verwys nie, gee hy wel in dié gedeelte voorskrifte aan sowel mans as vroue. Omdat hierdie voorskrifte wel as voorskrifte vir die huwelik kan dien (Breed, 
2006a:247-263), is dit baie moontlik dat Paulus in dié gedeelte die suiwer leer aangaande die huwelik teenoor die vals leer wat verkondig is, stel. Dit is egter belangrik om na te gaan of hierdie gedeelte spesifiek as teenvoeter kan dien vir die vals leer wat aangaande die huwelik verkondig is.

\section{Die moontlikheid dat 1 Timoteus 2:8-15 bedoel was as bestryding van die vals leer wat aangaande die huwelik in Efese verkondig is}

Daar word eerstens ondersoek gedoen of die voorskrifte aan vroue (1 Tim. 2:9-15) as teenvoeter sou kon dien vir die vals leer wat in Efese aangaande die huwelik verkondig is. Daarna word aandag gegee aan die voorskrifte vir mans (1 Tim. 2:8).

\subsection{Paulus se voorskrifte aan vroue}

\subsubsection{Beskeidenheid en ingetoënheid van getroude vroue teenoor seksuele losbandigheid}

Dit is waarskynlik dat getroude vroue wat die vals leraars sou navolg, 'n lae dunk van hulle huwelike sou hê en ook nie veel waarde sou heg aan huwelikstrou nie. Dit sou kon verklaar waarom Paulus vereis dat vroue hulle beskeie en ingetoë moet klee en nie seksueel verleidend nie (vgl. Groenewald, 1977:36; Kelly, 1972:66 en Mounce, 2000:109 wat aantoon dat die woorde aỉov̂s en $\sigma \omega \phi \rho o \sigma u ́ v \eta s$ in 2:9 met die seksuele verband kan hou).

\subsection{2 'n Erkenning van die man se hoofskap in die huwelik teenoor die verwerping daarvan}

Indien die gelowige vroue in Efese die leer van die vals leraars sou aanvaar en die huwelik sou minag, sou dit direkte gevolge hê vir die gesagsverhouding in die huwelik. Dit is moontlik dat vroue wat die vals leer aanvaar, opstandig sou wees oor die man se hoofskap (soos Paulus dit byvoorbeeld in Efesiërs 5 uiteensit). Hulle sou nie bereid wees om die leiding van hulle mans te aanvaar nie. Dit sou verduidelik waarom Paulus in 1 Timoteus 2:11 van vroue verwag om met innerlike kalmte 8 van hulle mans te leer. ${ }^{9}$ Dit sou ook

8 Uit Breed (2006a:254-265) se bestudering van 1 Timoteus 2:11 is dit duidelik dat Paulus die woord jंouxía moontlik in die semantiese veld Probleme, 
verduidelik waarom Paulus in 1 Timoteus 2:12 van gelowige vroue verwag om nie aan hulle mans voor te skryf en op dié wyse oor hulle gesag uit te oefen nie. 10

\subsubsection{Suiwer begronding vir die voorskrifte aan vroue teenoor vals begronding}

Omdat die vals leraars hulle verkondiging op die Ou Testament begrond het (vgl. 3.5), sou verwag kon word dat Paulus in sy bestryding van die leer hom op die Ou Testament sou beroep. Wanneer hy hulle vals verkondiging aangaande die eet van kos (vgl. 1 Tim. 4:3) bestry, beroep hy hom ook in 4:3-4 op die Ou Testament (vgl. 3.5). In hierdie opsig sou Paulus se verwysing in 1 Timoteus 2:13-15 na Genesis 2 en 3 goed inpas. Dit sou as begronding uit die Ou Testament kon dien waarom getroude vroue nie aan die vals leraars gehoor moet gee om hulle mans se gesag te verwerp nie.

\subsubsection{Die suiwer leer aangaande kinders in die wêreld bring teenoor ' $n$ vals siening daarvan}

Die leer dat die mense nie moet trou nie, sou nie slegs vir die gesagsverhouding in die huwelik gevolge inhou nie. Wie die huwelik verwerp, sou waarskynlik ook neersien op kinders in die wêreld bring. Dit sou kon verklaar waarom Paulus in 2:15 geboorte skenk in 'n oorweldigende sterk positiewe lig stel. 'n Vrou wat "in geloof en liefde en heiligheid bly met ingetoënheid" (2:15), sal nie op kinders baar neersien nie en is iemand wat gered is. ${ }^{11}$

Verligting, Gunstige omstandighede vir die betekenis 'n Staat van onversteurbare stilte en kalmte kon gebruik (vgl. ook Louw \& Nida, 1988:247).

9 Breed (2006a:254-256) toon aan dat dit moontlik is dat Paulus in 2:11 van getroude vroue verwag om in onderdanigheid van hulle mans te leer.

10 Dit is moontlik om Paulus se voorskrifte in 1 Timoteus 2:12 so te verstaan dat hy vroue verbied om hulle mans se hoofskap te ontken deur vir hulle mans voor te skryf . Deur vir hulle mans voor te skryf, sou hulle oor hulle mans gesag uitoefen (Breed, 2006a:254-259).

11 Dit blyk uit Breed (2006b:453-463) se studie van 1 Timoteus 2:15 dat Paulus nie in hierdie vers aandui dat vroue hulle redding kan bewerk deur geboorte te skenk nie. Breed toon aan dat Paulus in dié vers duidelik maak dat 'n vrou wat geboorte skenk dit as 'n voorreg beskou wat sy van God ontvang het, en daarmee toon dat sy die suiwer leer aanvaar en daarom iemand is wat gered is. 


\subsection{Paulus se voorskrifte aan mans}

\subsubsection{Die eenheid in die huwelik teenoor toorn en twis}

Indien die leraars se verkondiging aangaande die huwelik die gelowiges se huwelik sou beïnvloed, sou dit beslis die eenheid tussen mans en vroue in die huwelik beïnvloed. Wanneer getroudes nie hulle huwelik hoog ag nie, sal daar toorn en twis ontstaan. Dit sou verklaar waarom Paulus in 1 Timoteus 2:8 na toorn en twis verwys. Mans word daarvoor verantwoordelik gehou om te sorg dat daar nie toorn en twis is wat hierdie eenheid tussen man en vrou sal verbreek nie.

\subsubsection{Verantwoording voor God teenoor die vals leraars se begronding op die Ou Testament}

Hoewel die leer van die vals leraars tot die verbrokkeling van die huwelik sou lei en daar in die huwelik toorn en twis sou wees, het die vals leraars hulle steeds op goddelike gesag beroep. Hulle het immers hulle leer op die Ou Testament gegrond (vgl. 3.5). Paulus beroep hom ook in 2:8 op goddelike gesag. Hy wil dat mans hulle voor God verantwoord. Voordat hulle tot God bid, moet hulle eers seker maak dat hulle van alle toorn en twis gereinig is.

\subsubsection{Verantwoordelikheid in alle opsigte, teenoor geen verantwoordelikheid, soos deur die vals leraars voorgestaan}

Indien mans die vals leer in Efese sou aanvaar en hulle huwelike sou minag, sou dit daartoe lei dat hulle hulle verskillende verantwoordelikhede in die huwelik nalaat. Dit sou kon verklaar

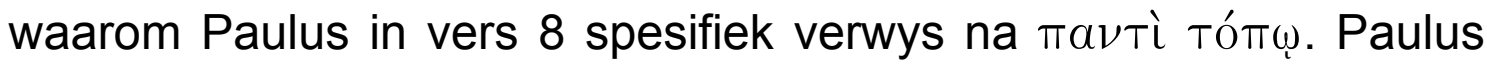
wil dat mans al hulle verantwoordelikhede12 in die huwelik nakom. Voordat hulle bid, moet hulle sorg dat daar nie ten opsigte van enige van hulle verantwoordelikhede in die huwelik toorn en twis voorkom nie.

12 Die woord tópos kan in die semantiese veld Doen gebruik word en wel vir die betekenis 'n Rol wat aktiwiteit en verantwoordelikheid inhou (Vgl. Breed, 2006a:252). 


\subsubsection{Timoteus 2:8-15 as suiwer leer aangaande die huwelik, teenoor die vals leer wat in Efese verkondig is}

Uit die voorgaande blyk dat 1 Timoteus 2:8-15 baie goed sou kon dien as positiewe voorskrifte wat Paulus stel teenoor die vals leer wat die leraars in Efese aangaande die huwelik verkondig het.

\section{Samevatting van die gevolgtrekkings aangaande die verstaan van 1 Timoteus 2:8-15}

- Die ondersoek in hierdie artikel na die vals leer wat in Efese verkondig is, het aangedui dat die leraars spesifiek oor die huwelik gehandel het. Daar sou verwag kon word dat Paulus in die brief wat hy aan Timoteus rig en waarin hy die leer van die leraars bestry, behoorlike aandag sal gee aan die suiwer leer aangaande die huwelik.

- In die ondersoek na die doel van Paulus met sy brief aan Timoteus, het dit geblyk dat die gelowiges se gedrag en die boodskap wat dit aan die ongelowiges oordra, sentraal staan in die doel van die brief. Daaruit was dit duidelik dat dit meer waarskynlik sou wees dat Paulus in 1 Timoteus 2:8-15 oor die gedrag van mans en vroue in die algemeen of in die huwelik sal handel as oor hulle gedrag in die erediens. Die gelowiges se gedrag in die erediens is immers net by uitsondering vir die ongelowiges sigbaar. Daar is egter aanvaar dat dit nie 'n deurslaggewende aanduiding is dat Paulus nié in die gedeelte oor die erediens handel nie, aangesien hy dit om een of ander rede nodig kon ag om in die brief aan Timoteus sake aan te raak wat nie direk inpas by die doel van die brief nie.

- Uit die ondersoek na die gedagtestruktuur van 1 Timoteus 2, het dit geblyk dat Paulus in die gedeelte oor die waardige optrede van mans en vroue in ooreenstemming met God se wil handel optrede wat tot redding van mense en tot kennis van die waarheid sal lei. Daaruit kan afgelei word dat dit meer waarskynlik is dat Paulus in 1 Timoteus 2 oor die gedrag van mans en vroue in die gewone lewe of in die huwelik handel, as oor hulle optrede in die erediens.

- Dit was in die bestudering van die huwelik in 1 Timoteus duidelik dat Paulus nêrens in die gedeeltes waarin hy na die huwelik verwys, positiewe voorskrifte gee waarin hy die suiwer leer aangaande die huwelik teenoor die vals leer wat die leraars in Efese verkondig het, stel nie. Dit het egter geblyk dat, hoewel Paulus in 1 Timoteus 2:8-15 nie uitdruklik die huwelik vermeld 
nie, hy wel in dié gedeelte voorskrifte aan sowel mans as vroue gee wat as voorskrifte vir die huwelik sou kon dien. Daar kan dus afgelei word dat Paulus waarskynlik in 1 Timoteus 2:8-15 duidelik maak wat die suiwer leer aangaande die huwelik is, en dat hy dit stel teenoor dit wat die vals leraars aangaande die huwelik verkondig het.

- Dit het geblyk dat 1 Timoteus 2:8-15 baie goed sou dien as positiewe voorskrifte waarmee Paulus die vals leer bestry wat in Efese aangaande die huwelik verkondig is.

\section{Finale gevolgtrekking}

Paulus gee waarskynlik in 1 Timoteus 2:8-15 voorskrifte vir die gedrag van mans en vroue in die huwelik.

\section{Materiaal vir verdere ondersoek}

1 Timoteus 2 vertoon duidelike ooreenkomste met veral twee ander gedeeltes in die Skrif, te wete 1 Korintiers 14:34 en 1 Petrus 3:1-7. 'n Studie waarin 1 Timoteus 2 met hierdie gedeeltes en ander gedeeltes vergelyk word, kan moontlik verdere lig werp op die vraag na die konteks waarbinne 1 Timoteus 2 verstaan moet word.

\section{Geraadpleegde bronne}

BARNETT, P.W. 1989. Wives and woman's ministry (1 Timothy 2:11-15). The Evangelical Quarterly, 61(3):225-238.

BORSE, U. 1985. 1. und 2. Timotheusbrief, Titusbrief. Stuttgart: Verlag Katholisches Bibelwerk. (Stuttgarter Kleiner Kommentar: Neues Testament, 13.)

BREED, D.G. 2006a. 1 Timoteus 2:8-15: voorskrifte vir gedrag in die erediens, in die gewone lewe of in die huwelik? 'n Eksegetiese studie. In die Skriflig, 40(2):247-263.

BREED, D.G. 2006b. Genesis 2 en 3 in 1 Timoteus 2: 'n motivering vir gedrag in die erediens, die gewone lewe of die huwelik? In die Skriflig, 40(3):453463.

DAVIES, M. 1996. The Pastoral Epistles. Sheffield: Sheffield Academic Press.

DE KRUIJF, Th. C. 1966. De Pastorale Brieven. Roermond: Romen. (Het Nieuwe Testament.)

GROENEWALD, E.P. 1977. Die Pastorale Briewe. Kaapstad: N.G. Kerk Uitgewers.

GUTHRIE, D. 1978. The Pastoral Epistles. Grand Rapids: Eerdmans. (Tyndale New Testament Commentaries.)

HARRIS, T.J. 1990. Why did Paul mention Eve's deception? A critique of P.W. Barnett's interpretation of 1 Timothy 2. The Evangelical Quarterly, 62:335352. 
HOLMES, J.M. 2000. Text in a whirlwind: a critique of four exegetical devices as 1 Timothy 2:9-15. Sheffield: Sheffield Academic Press.

KELLY, J.N.D. 1972. A commentary on the Pastoral Epistles: I and II Timothy, Titus. London: Black. (Black's New Testament Commentaries.)

KIDD, R.M. 1990. Wealth and beneficence in the Pastoral Epistles: a "bourgeois" form of early Christianity? Atlanta: Scholars Press.

LOUW, J.P. \& Nida, E.A. 1988. Greek-English lexikon of the New Testament based on semantic domains. Vol. 1. New York: United Bible Societies.

MOUNCE, W.D. 2000. Pastoral Epistles. Nashville: Thomas Nelson. (Word Biblical Commentary, 46.)

OKORIE, A.M. 1988. Marriage in the Pastoral Epistles. Michigan: UMI Dissertation Information Service.

RIDDERBOS, D. 1967. De Pastorale Brieven. Kampen: N.V. Uitgeversmaatschappij. (Commentaar op het Nieuwe Testament.)

RIDDERBOS, H. 1979. Paul: an outline of his theology. Grand Rapids: Eerdmans.

SCHREINER, T.R. 1995. An interpretation of 1 Timothy 2:9-15: a dialogue with scholarship. (In Köstenberger, A.J., Schreiner, T.R. \& Baldwin, H.S., eds. Woman in the church: a fresh analysis of 1 Timothy 2:9-15. Michigan: Baker Books. p. 105-154.)

SPICQ, C. 1969. Saint Paul: les Építres Pastorales. Paris: Gabalda.

SUMNEY, J.L. 1999. "Servants of Satan", false brothers and other opponents of Paul. Sheffield: Sheffield Academic Press.

TOWNER, P.H. 1989. The goal of our instruction: the structure of the theology and ethics in the Pastoral Epistles. Sheffield: Sheffield Academic Press.

VERNER, C.V. 1983. The household of God: the social world of the Pastoral Epistles. California: Scholars Press.

VRIEZEN, Th. C. 1977. Hoofdlijnen der theologie van het Oude Testament. Wageningen: Veenman.

WIEBE, B. 1994. Two texts on women (1 Tim. 2:11-15; Gal. 3:26-29): a test of interpretation. Horizons in Biblical Theology: an international Dialogue, 16(1):54-85.

YOUNG, F. 1994. The theology of the Pastoral Letters. Cambridge: Cambridge University Press.

\section{Kernbegrippe:}

\section{Timoteus}

huwelik

openbare erediens

vroue

Key concepts:

1 Timothy

marriage

public worship

woman 